\title{
Association between red cell distribution width and mean platelet volume with appendicitis: a myth or a fact?
}

\author{
Dinc $\mathrm{T}^{1}$, Senol K ${ }^{1}$, Yildiz $\mathrm{B}^{1}$, Kayilioglu $\mathrm{I}^{1}$, Sozen $\mathrm{I}^{1}$, Coskun $\mathrm{F}^{2}$ \\ Ankara Numune Teaching Hospital General Surgery Clinic, Kizilay, Ankara, Turkey. \\ baris104@yahoo.com
}

\section{ABSTRACT}

OBJECTIVES: The aim of our study was to identify if there was a relation between red cell distribution width, mean platelet volume, platelet distribution width, leukocyte count and thrombocyte count at the time of presentation to hospital and acute appendicitis.

BACKGROUND: Acute appendicitis is one of the most common surgical emergencies. Misinterpretation of symptoms and findings in acute appendicitis may lead to removal of normal appendix and delayed diagnosis can result in perforation and peritonitis. Many studies tried to delineate the relation between acute appendicitis and laboratory findings. Latest studies focused on components of complete blood count such as red cell distribution width and mean platelet volume.

METHODS: This was a retrospective clinical study that enrolled 638 patients with abdominal pain and open appendectomy for acute appendicitis. Complete blood count results including red cell distribution width were retrieved from medical charts of patients and analyzed.

RESULTS: There was no statistically significant difference between appendicitis, non pathological appendix and perforated appendicitis in terms of red cell distribution width or other blood count components except leukocyte level.

CONCLUSION: Despite current findings in medical literature indicating predictive value of red cell distribution width in acute appendicitis; its utility for differential diagnosis might be overestimated (Tab. 1, Ref. 22). Text in PDF www.elis.sk.

KEY WORDS: acute appendicitis, red cell distribution width, mean platelet volume, platelet distribution width.

\section{Introduction}

Acute appendicitis (AA) is one of the most common surgical emergencies where delayed diagnosis might lead to mortality and morbidity (1). Lower quadrant abdominal pain, nausea and findings of local peritonitis can be seen in $70-80 \%$ of patients in AA $(1,2)$. Misinterpretation of these symptoms and findings may lead to removal of normal appendix and delayed diagnosis can result in perforation and peritonitis (3). Several studies showed that perforation rate and negative laparotomy rates are $20 \%$ and $30 \%$, respectively in suspected AA $(1,4)$. Ultrasonography (US) and computerized tomography $(\mathrm{CT})$ can be used in diagnosis of AA $(5,6)$. Many studies tried to delineate the relation between AA and laboratory findings $(7,8)$. Latest studies focused on whether red cell distribution width (RDW) and mean platelet volume (MPV) could be utilized as early predictors in AA $(9,10,11)$.

The aim of our study was to identify if there was a relation between AA and red cell distribution width (RDW), mean platelet

\footnotetext{
${ }^{1}$ Ankara Numune Teaching Hospital General Surgery Clinic, Kizilay, Ankara, Turkey, and ${ }^{2}$ Hitit University Faculty of Medicine, Corum Teaching Hospital, General Surgery Clinic Kizilay, Ankara, Turkey

Address for correspondence: B. Yildiz, MD, Ankara Numune Teaching Hospital General Surgery Clinic, Kizilay, Selanik cad 29/2, 06650 Ankara, Turkey.

Phone: +90.532 .4454655 , Fax: +90.312 .4241520$
}

volume (MPV), platelet distribution width (PDW), leukocyte count (LEU), thrombocyte count (PLT), neutrophil count (NEU) and lymphocyte count (LYM) at the time of presentation to hospital.

\section{Materials and methods}

This was a retrospective clinical study that enrolled 638 patients who were submitted to Ankara Numune Teaching Hospital Emergency Surgery Clinic between 03/01/2010 - 03/01/2012 with abdominal pain and had open appendectomy for acute appendicitis. This study was approved by Ankara Numune Teaching Hospital Ethics Committee. Diagnosis of appendicitis was made based on patient history and physical examination, laboratory results, US or CT findings. RDW, MPV, PDW, LEU, PLT, NEU, LYM test results retrieved from complete blood count measured with a standart machine (Coulter ${ }^{\circledR}$ LH780- Beckman Coulter, Inc. Tokyo, Japan) were recorded. Demographic findings were also analyzed along with pathology results. According to pathology report patients were divided into three groups: Group 1 (no pathological finding), Group 2 (appendicitis), Group 3 (perforated appendicitis).

\section{Statistical analysis}

Statistical analysis was performed using SPSS 15.0 for Windows. Analysis of the data distribution was assessed by the Kolmogorov-Smirnov test. For normally distributed data, the null 
Tab. 1. Comparison of age, gender and laboratory findings in patient groups.

\begin{tabular}{|c|c|c|c|c|c|}
\hline & & $\begin{array}{c}\text { Group } 1(\mathrm{n}=23) \\
(\text { Mean } \pm \text { SD })\end{array}$ & $\begin{array}{l}\text { Group } 2(n=498) \\
(\text { Mean } \pm \text { SD })\end{array}$ & $\begin{array}{l}\text { Group } 3(\mathrm{n}=117) \\
(\text { Mean } \pm \text { SD })\end{array}$ & p* \\
\hline$\overline{\text { Age }}$ & & $28.86 \pm 11.34$ & $32.73 \pm 12.99$ & $34.74 \pm 15.54$ & 0.266 \\
\hline \multirow{2}{*}{ Gender } & Female (\%) & $17(\% 2,67)$ & $217(\% 34.01)$ & $34(\% 5.33)$ & \multirow[t]{2}{*}{0.002} \\
\hline & Male (\%) & $6(\% 0,94)$ & $281(\% 44.04)$ & $83(\% 13.01)$ & \\
\hline \multicolumn{2}{|c|}{ RDW (\%) } & $13.38 \pm 1.56$ & $12.92 \pm 1.56$ & $12.91 \pm 1.21$ & 0.285 \\
\hline \multicolumn{2}{|c|}{ MPV (fL) } & $8.16 \pm 1.16$ & $8.69 \pm 3.35$ & $8.26 \pm 1.06$ & 0.767 \\
\hline \multicolumn{2}{|c|}{ PDW (\%) } & $15.95 \pm 1.53$ & $15.42 \pm 2.13$ & $15.65 \pm 1.88$ & 0.800 \\
\hline \multicolumn{2}{|c|}{$\mathrm{LEU}\left(\mathrm{x} 10^{3} \mu \mathrm{L}\right)$} & $10.84 \pm 3.41$ & $13.36 \pm 4.22$ & $15.86 \pm 4.59$ & 0.0001 \\
\hline \multicolumn{2}{|c|}{ PLT $\left(x 10^{3} \mu \mathrm{L}\right)$} & $238.04 \pm 69.03$ & $243.37 \pm 68.96$ & $245.15 \pm 58.47$ & 0.636 \\
\hline \multicolumn{2}{|c|}{$\mathrm{NEU}\left(\mathrm{x} 10^{3} \mu \mathrm{L}\right)$} & $8.02 \pm 3.29$ & $10.75 \pm 9.8$ & $12.35 \pm 4.51$ & 0.187 \\
\hline \multicolumn{2}{|c|}{$\mathrm{LYM}\left(\mathrm{x} 10^{3} \mu \mathrm{L}\right)$} & $1.95 \pm 0.691$ & $2.11 \pm 0.88$ & $2.21 \pm 1.316$ & 0.716 \\
\hline
\end{tabular}

$* \mathrm{p}<0.05$ is accepted as statistically significant. RDW - Red cell distribution width, MPV - Mean platelet volume, PDW - Platelet distribution width, LEU - Leukocyte, PLT - Platelet, NEU - Neutrophil, LYM - Lymphocyte

hypothesis was based on the assumption that no difference in values existed between the 3 groups that were studied in the present trial. One-way ANOVA for 3 independent samples was used for inter-arm comparisons. In the case of unequal data distribution, the Kruskal-Wallis test (nonparametric independent-group comparison) was used to compare groups. Mann-Whitney U Test was applied to compare different groups among themselves. Demographic variables were analyzed by means of $\chi^{2}$ analysis. Statistical significance was set at a $5 \%$ level (2-sided).

\section{Results}

There were 268 (42\%) females and 370 (58\%) males. Mean age of patients was $32.82 \pm 13.56$ (min: 10 , max: 84 ). There were 23 patients in Group 1, 498 patients in Group 2 and 117 patients in Group 3. Distribution of patients in groups is shown in Table 1.

RDW, MPV, PDW, LEU, PLT, NEU, LYM values for each group were analyzed and statistically compared. There was no statistically significant difference $(p>0.05)$ between groups in MPV, RDW, PDW, PLT, NEU and LYM values. On the other hand, the difference in LEU values was statistically significant $(\mathrm{p}=0.0001)($ Tab. 1).

\section{Discussion}

AA is a frequently encountered condition in emergency clinics while its overall lifetime risk is $8.6 \%$ for males and $6.7 \%$ for females and its frequency increases in second and fourth decades $(12,13,14)$. In our study, mean age was 32 and AA rate was higher in males as indicated in medical literature.

Delayed diagnosis in AA can lead to perforation and peritonitis while fear of these complications might lead to negative laparotomies. Especially in rural hospitals where CT and/or US is not available, laboratory tests with high sensitivity and specifity become essential in reaching a reliable differential diagnosis. Utilization of RDW for diagnosis of pancreatitis and mesenteric ischemia as proven by Senol et al is an example for such a scenario $(15,16)$.

The principal use of RDW is in differential diagnosis of iron deficiency anemia, thalassemia and hemomoglobinopathies. But there are studies which showed that RDW could be used in diag- nosis of AA, colonic cancer, cardiac diseases and celiac disease $(17,18,19)$. Narci et al showed that preoperative low RDW is associated with AA (11). Despite these associations we could not find a relationship between AA and RDW in our study.

Apart from RDW high and low MPV values were also found to be associated with AA $(9,10)$ although it was indicated that MPV is not a predictive factor for AA diagnosis in pediatric population (20). In our study, preoperative MPV was not helpful in AA diagnosis.

Leukocytosis is the earliest and the most common laboratory finding in AA $(1,21)$. In our study LEU was the only laboratory test associated with AA diagnosis. LEU was higher in patients with pathological diagnosis of AA and in those with perforated appendicitis. Despite this association, subgroups of LEU (ie NEU and LYM) were not related with AA diagnosis

The changes in platelet values in sepsis are well known. Patients with severe sepsis have lower platelet count and increased PDW compared to patients with sepsis (22). Although numerous studies evaluated changes of MPV in AA there is no study in medical literature assessing the relation between PDW, PLT and AA. In our current study we could not show any statistically significant change in these two variables in AA. Our study is the first in medical literature evaluating the interaction between PDW, PLT and AA.

The shortcoming of our study is as this was a retrospective study we could not evaluate other parameters of inflammation/ infection such as C-reactive protein or CD64+ on neutrophils.

\section{Conclusion}

Complete blood count is an inexpensive, easily accessible and routinely performed test for almost all patients admitted to primary care health facilities. Endeavours to utilize components of this simple laboratory study for AA raised hope in rural and third world country emergency settings where more advanced diagnostic methods are not available.

Despite current findings in medical literature indicating predictive value of RDW in AA, we could not verify this association in our study. This was also true for MPV, PDV and PLT, NEU and LYM. Our findings question the utility of RDW and other complete blood count laboratory findings for diagnosis of AA. Thus 
we conclude that utility of RDW or MPV for differential diagnosis of AA might be overestimated.

\section{References}

1. Andersson RE. Meta-analysis of the clinical and laboratory diagnosis of appendicitis. Br J Surg 2004; 91 (1): 28-37.

2. Karagulle E, Turk E, Ezer A, Nursal TZ, Kulaksizoglu S, Moray G. Value of Plasma Viscosity in Acute Appendicitis: A Preliminary Study. J Med Med Sci 2010; 1 (9): 423-425.

3. Prystowsky JB, Pugh CM, Nagle AP. Current problems in surgery. Appendicitis. Curr Probl Surg 2005; 42: 688-742.

4. Storm-Dickerson TL, Horattas MC. What have we learned over the past 20 years about appendicitis in the elderly? Am J Surg 2003; 185 : 198-201.

5. Kaiser S, Frenckner B, Jorulf HK. Suspected appendicitis in children: US and CT- a prospective randomized study. Radiology 2002; 223 : 633-638.

6. Rao PM, Rhea JT, Novelline RA, Mostafavi AA, McCabe C. Effect of computed tomography of the appendix on treatment of patients and use of hospital resources. N Engl J Med 1998; 338: 141-146.

7. Yang HR, Wang YC, Chung PK, Chen WK, Jeng LB, Chen RJ. Laboratory tests in patients with acute appendicitis. ANZ J Surg 2006; 76: 71-74.

8. Laméris W, Van Randen A, Go PM, Bouma WH, Donkervoort SC, Bossuyt PM. Single and combined diagnostic value of clinical features and laboratory tests in acute appendicitis. Academic Emergency Medicine, 2009; 16 (9): 835-842.

9. Narci H, Turk E, Karagulle E, Togan T, Karabulut K. The Role of Mean Platelet Volume in the Diagnosis of Acute Appendicitis: A Retrospective Case-Controlled Study. Iran Red Crescent Med J 2013 December; 15 (12): e11934.

10. Albayrak Y, Albayrak A, Albayrak F et al. Mean Platelet Volume: A New Predictor in Confirming Acute Appendicitis Diagnosis. Clinical and Applied Thrombosis/Hemostasis 2011; 17 (4): 362-366.
11. Narci H, Turk E, Karagulle E, Togan T, Karabulut K. The role of red cell distribution width in the diagnosis of acute appendicitis: a retrospective case-controlled study. World J Emerg Surg 2013; 8: 46-52.

12. Liu CD, McFadden DW. Acute abdomen and appendix. Surgery: scientific principles and practice Philadelphia: Lippincott, 1997, 1246-1261.

13. Humes DJ, Simpson J. Acute appendicitis - clinical Review. BMJ 2006; 333: 530-534.

14. Körner H, Söndenaa K, Söreide JA et al. Incidence of acute nonperforated and perforated appendicitis: age-specific and sex-specific analysis. World J Surg 1997; 21: 313-317.

15. Şenol K, Saylam B, Kocaay F, Tez M. Red cell distribution width as a predictor of mortality in acute pancreatitis. Am J Emerg Med 2013; 31 (4): 687-689.

16. Bilgiç I, Dolu F, Şenol K, Tez M. Prognostic significance of red-cell distrubition width in acute mesenteric ischemia. Perfusion 2014 May. doi: $10.1177 / 0267659114534289$

17. Harmanci O, Kav T, Sivri B. Red cell distribution width can predict intestinal atrophy in selected patients with celiac disease. J Clin Lab Anal 2012; 26: 497-502.

18. Kim J, Kim K, Lee JH et al. Red blood cell distribution width as an independent predictor of all-cause mortality in out of hospital cardiac arrest. Resuscitation 2012; 83: 1248-1252.

19. Spell DW, Jones DV Jr, Harper WF, David BJ. The value of a complete blood count in predicting cancer of the colon. Cancer Detect Prev 2004; $28: 37-42$.

20. Uyanik B, Kavalci C, Arslan ED, et al. Role of Mean Platelet Volume in Diagnosis of Childhood Acute Appendicitis. Emeg Med Int 2012; 2012: 4.

21. Sadaka F, O'Brien J, Prakash S: Red cell distribution width and outcome in patients with septic shock. J Intensive Care Med 2013; 28 : 307-313.

22. Guclu E, Durmaz Y, Karabay O. Effect of severe sepsis on platelet count and their indices. Afr Health Sci 2013; 13 (2): 333-338.

Received July 18, 2014. Accepted February 20, 2015. 